\title{
Oxidative Stress and Haemolytic Anaemia In Dogs and Cats: A Comparative Approach
}

\author{
Gibson JS ${ }^{*}$, Wadud R${ }^{1}$, Lu DCY1, Brewin JN² and Rees DC ${ }^{2}$ \\ ${ }^{1}$ Department of Veterinary Medicine, Madingley Road, Cambridge, UK \\ ${ }^{2}$ Department of Paediatric Haematology, King's College Hospital, London, UK
}

*Corresponding author: John S. Gibson, Department of Veterinary Medicine, Madingley Road, Cambridge, CB3 0ES, UK; E-mail: jsg1001@cam.ac.uk

Received: October 15, 2019; Accepted: October 23, 2019; Published: October 31, 2019

\begin{abstract}
Oxidative stress contributes to Haemolytic Anaemia in many species including dogs and cats, as well as in humans. Red cells are exposed to a continual oxidant challenge, both endogenously from within the red cells themselves and also exogenously from other tissues, and from ingested or administered oxidants. When the oxidative challenge exceeds the antioxidant provisions of the red cell, damage occurs in the form of lipid and protein peroxidation, cytoskeletal crosslinking, oxidation of haemoglobin to methemolglobin, and precipitation of denatured sulphhaemoglobin as Heinz bodies. These deleterious sequelae produce fragile red cells with reduced lifespan, and result in poorer oxygen delivery to tissues, intravascular haemolysis, anaemia, haemoglobinuria and jaundice. A number of features increase the risk of oxidant damage in dogs and cats. Thus dog red cells have low levels of the antioxidant enzyme catalase. Cat haemoglobin has at least four times as many readily oxidizable thiol residues compared to most species, whilst their hepatic capacity for glucuronidation is much reduced, which can result in greater accumulation of oxidants. Like humans, both species may also be exposed to excess oxidants from systemic diseases such as diabetes mellitus, hepatic lipidosis, hypophosphatemia and neoplasias. Iatrogenic oxidants include drugs such as acetaminophen and other non-steroidal anti-inflammatory compounds. Ingested toxins include heavy metals, particularly important in dogs with their increased propensity for scavenging. Ingestion of feeds containing products from Allium species of plants has also long been associated with red cell oxidative damage and Heinz body formation in both dogs and cats. Though less common than in humans, there are occasional congenital enzyme deficiencies which reduce the enzymatic oxidant defence of the red cells in these species. Treatment usually relies on removal of the oxidant challenge or support against the resulting anaemia. Specific antioxidants currently lack efficacy but analogy with human medicine suggests that a range possible antioxidants may be potentially beneficial.
\end{abstract}

Key words: Antioxidant Defence, Dogs and Cats, Haemolytic Anaemia, Oxidative Stress

\section{Introduction}

Red cells occupy a unique position within the vertebrate body. When mature, they are enucleated and lack cytoplasmic organelles [1]. As such, they are therefore unable to carry out ribosomal protein synthesis or mitochondrial oxidative phosphorylation. They are dependent upon glycolysis (or the Emden-Meyerhoff pathway) for whatever ATP supply is required to maintain their osmotic integrity, through various ion pumps, and for other energy requiring events, like synthesis of reduced glutathione, one of their main antioxidant defences [2,3]. All vertebrate red cells have the main task of carriage of blood gases, oxygen from respiratory tissues and carbon dioxide from metabolically active tissues. Notwithstanding, there are some surprising species differences in function, which are significant both physiologically and pathologically [1]. For example, most vertebrate red cells contain high levels of $\mathrm{K}^{+}$and low levels of $\mathrm{Na}^{+}$, whose gradients are maintained through the functioning of the ATP-dependent $\mathrm{Na}^{+} / \mathrm{K}^{+}$pump in the red cell membrane. This pump, together with a normally low passive "leak" to $\mathrm{Na}^{+}$and $\mathrm{K}^{+}$prevent osmotic swelling which would otherwise occur through the large cytoplasmic load of impermeable protein, especially haemoglobin $(\mathrm{Hb})$, and other molecules, notably organic phosphates [4]. By contrast, dog and cat red cells are usually low in $\mathrm{K}^{+}$and high in $\mathrm{Na}^{+}$. When mature - but not during development - their red cells lack $\mathrm{Na}^{+} /$ $\mathrm{K}^{+}$pumping capacity and rather they use combinations of $\mathrm{Ca}^{2+}$ pumps and $\mathrm{Na}^{+} / \mathrm{Ca}^{2+}$ exchange proteins to maintain osmotic equilibrium [5]. An exception is high $\mathrm{K}^{+}$-containing red cells of certain Asian breeds for example, the Japanese Shibas and Akitas [6] which retain $\mathrm{Na}^{+} /$ $\mathrm{K}^{+}$pumping capacity, and also high levels of the antioxidant reduced glutathione, throughout their lifespan. There are also other differences in physiology of dog and cat red cells pertinent to the subject of this review, and which are considered later.

\section{Dog and Cat Red Cells}

In the absence of shear stress, human red cells have the classic biconcave shape with a diameter of about $8 \mu \mathrm{m}$. Dog and cat red cells have a similar appearance but are somewhat smaller, at $7 \mu \mathrm{m}$ and 5.5-6.3 $\mu \mathrm{m}$, respectively [7]. Cat red cells, in particular, show a degree of anisocytosis and also tend to lack the central pallor which is easily recognizable in the more obviously biconcave shape of dog and human red cells. The oxygen-carrying pigment $\mathrm{Hb}$ is found in all vertebrates with the exception of a few species of Antarctic fish [8]. The latter live at subzero temperatures and thereby survive and carry 
out aerobic metabolism using only the additional oxygen dissolved in plasma at these low temperatures. There are species variations in $\mathrm{Hb}$, however. In this context, cat $\mathrm{Hb}$ is noticeable in having $8-10$ readily oxidizable sulphydryl groups $[9,10]$ whilst most other species including humans and dogs have only two main ones, represented by the highly conserved $\beta 93$ cysteines $[11,12]$. Cat $\mathrm{Hb}$ also readily dissociates from the usual tetrameric form to dimers [13] which have a greater tendency for autoxidation [14]. Heinz bodies, denatured, precipitated sulphHb, are a special feature of oxidative stress [14]. They are also found in the circulation of healthy cats, however, at up to $5-10 \%$ red cells, presumably because of their greater number of oxidative sites in $\mathrm{Hb}$ and impaired red cell antioxidant defence, together with the poor ability of the non-sinusoidal feline spleen to remove Heinz body-containing red cells [15]. Cats also have two main Hbs A and B $[9,16]$. HbA is most prevalent in domestic short- and long-haired cats have $\mathrm{HbA}$ (98 \%) but a few breeds have greater levels of $\mathrm{HbB}$ (eg $10 \%$ Persians and $14 \%$ in Abyssinians, with as much as 50 $\%$ in Devon Rexs) and geographically to occur $\{$ eg [17]\}. The oxygen affinity of many species is reduced by organic phosphates, especially 2,3-diphosphoglycerate (2,3-DPG or 2,3-biphosphoglycerate), but cat $\mathrm{HbA}$ is less responsive to the reduction in $\mathrm{P} 50$ whilst $\mathrm{HbB}$ does not respond at all $[18,19]$. Cat red cells also have low levels of 2,3-DPG [20] which is understandable if it has little regulatory effect on oxygen affinity. Dogs have also several Hbs and more than twelve blood groups [21] but react like human $\mathrm{Hb}$ to 2,3-DPG.

\section{Red Cell Metabolism}

Mature red cells lack mitochondria and are therefore dependent on anaerobic glycolysis for ATP synthesis [3]. Compared with the citric acid (Kreb cycle) of aerobic respiration this is relatively inefficient, producing two molecules of ATP per glucose moiety (compared with thirty six in mitochondrial aerobic respiration). Glycolysis comprises ten enzymatic steps [1], although the main rate limiting enzymes are hexokinase and pyruvate kinase, at the start and end of the chain, respectively. In addition to ATP, the pathway also syntheses reducing power in the form of NADH. NADH is necessary to reduce methaemoglobin (metHb) using methaemoglobin reductase (or cytochrome b reductase) - one of the main red cell antioxidant defences. An off-shoot of the glycolytic pathway called the pentose phosphate shunt (or hexose monophosphate shunt) is used to make the reducing compound NADPH, a substrate for glutathione reductase - a second main antioxidant enzyme - which reduces oxidised glutathione (GSSG) back to reduced glutathione (GSH). Under normal conditions, glycolysis uses the majority of glucose metabolised by the red cell, with the pentose phosphate shunt accounting for only about $10 \%$ of the flux. Inhibition of the first enzyme of the pentose phosphate shunt, glucose-6-phosphate dehydrogenase, by high NADPH / NADP ratios is responsible and this enzyme normally operates at only a low level of its maximum capacity. Under conditions of oxidative stress, however, as NADPH / NADP ratios fall, glucose is preferentially channelled along the pentose phosphate shunt. Interestingly, deoxyHb which preferentially binds to the cytoplasmic tail of the anion exchanger (or Band 3) displaces glycolytic and other enzymes so that deoxygenated red cells carry out more glycolysis, oxygenated ones produce more
NADPH $[22,23]$ providing a physiological switch to channel glucose through one or other pathways. In addition, the red cells of some species are less permeable to glucose, eg some fish and pigs $[1,24$, 25]. In these cases, the pentose phosphate shunt pathways can be used as an alternative to glycolysis for synthesis of ATP, metabolising nucleosides, such as inosine and metabolites of ribose, which enter into the distal part of the glycolytic pathway.

The third red cell metabolic pathway of note is the RapaportLuebering shunt (1950s). This uses the enzyme biphosphoglycerate mutase to produce 2,3-DPG (2,3-BPG) - apparently confined to cells of the erythroid lineage and placental cells [26] and accounts for about $20 \%$ of the glucose passing through glycolysis. There is a metabolic cost to this, as the Rapaport-Luebering shunt bypasses phosphoglycerate kinase with the loss of one ATP of the two molecules of ATP from metabolism of glucose. Congenital enzyme deficiencies in the red cell metabolic pathways have been well described in humans [2, 27]. Some genetic deficiencies have also been described in dogs and cats [Table 1]. Whilst oxidative threat is not the root of these conditions, a defect in antioxidant defences will accompany the inadequacies in glucose metabolism which underlie the loss of ATP, and which represents the main cause of red cell instability.

Table 1. Some inherited causes of haemolytic anaemia in dogs and cats.

\begin{tabular}{|l|l|}
\hline Catalase & American foxhound, beagle [55] \\
\hline Hereditary elliptocytosis & Band 4,1 deficiency [56] \\
\hline Hereditary spherocytosis & $\begin{array}{l}\text { Autosomal recessive trait in chondrodysplastic } \\
\text { Alaskan malamute dwarf dogs }\end{array}$ \\
\hline Hereditary stomatocytosis & Schnauzers [57,59] \\
\hline Methaemoglobin redutase & $\begin{array}{l}\text { Dogs (toy Alaskan Eskimo, miniature poodle, } \\
\text { cocker/poodle cross) and cats - domestic short } \\
\text { hair [60,61,62] }\end{array}$ \\
\hline Osmotic fragility syndrome & $\begin{array}{l}\text { Abyssinian, Somali, Siamese and domestic short } \\
\text { hair cats [63-64] }\end{array}$ \\
\hline $\begin{array}{l}\text { Phosphofructokinase (PFK) } \\
\text { deficiency }\end{array}$ & $\begin{array}{l}\text { English springer spaniels, American cocker } \\
\text { spaniels, whippets [65-66] }\end{array}$ \\
\hline $\begin{array}{l}\text { Pyruvate kinase (PK) } \\
\text { deficiency }\end{array}$ & $\begin{array}{l}\text { Basenjis, Cairn terrier, West Highland white } \\
\text { terriers, beagles, cairn terriers, miniature } \\
\text { poodles, dachshunds, Chihuahus, American } \\
\text { Eskimo toy dogs, pugs, American Labrador } \\
\text { retrievers; Abyssinian, Somali and domestic } \\
\text { shorthaired cats [67] }\end{array}$ \\
\hline
\end{tabular}

\section{Oxidative Challenge}

Red cells are also subject to considerable oxidative stress throughout their lifespan. Oxidative challenges arise from several underlying conditions and sources [28,29]. First, oxygen is potentially toxic and their function as the main oxygen-carrying cell of the body exposes them continually to the threat of oxygen damage. Whilst in other tissues, there is always some slippage of oxygen away from its mitochondrial function in aerobic respiration, which generates superoxide anion and other free radicals, in red cells, the ironcontaining $\mathrm{Hb}$ is the major source of reactive oxygen species [29, 
30]. The ferrous $\mathrm{Fe}^{2+}$ in heme groups is potentially unstable and liable to autoxidation to ferric $\mathrm{Fe}^{3+}$, generating superoxide and, through dismutation, hydrogen peroxide [31] which may be removed by one of the important red cell antioxidant enzymes, catalase. Heme iron is also able to take part in the Fenton and Haber-Weiss reactions to generate hydroxyl and other free radicals $[2,32]$. Red cell NADPH oxygenase is a further source of endogenous oxidants $[28,33]$. Around $0.5-3 \%$ red cell haemoglobin is oxidized daily [34], producing a constant source of methaemoglobin, although levels are usually kept below $1 \%$ through the reducing action of methaemoglobin reductase [35]. In addition, there is the threat from exogenous oxidants which may enter the circulation from other tissues, for example following ischaemia / reperfusion [36], or the action of xanthine oxidase on hypoxanthine [37] or also via ingested or iatrogenic oxidants [7]. Cat $\mathrm{Hb}$ more susceptible to oxidants (Harvey \& Kaneko 1976), especially feline $\mathrm{HbB}$ cf feline $\mathrm{HbA}$. Counterintuitively, dogs with red cells containing high levels of $\mathrm{K}^{+}$, and also high levels of the antioxidant reduced glutathione notably Japanese breeds [38] appear more susceptible to oxidative damage than the more common low $\mathrm{K}^{+}$ones. A number of systemic diseases are associated. Some of these include diabetes mellitus, hepatic problems, hyperthyroidism (especially in cats), neoplasia, severe hypophosphataemia (eg refeeding syndrome in cats) and uraemic syndrome.

Oxidative red cell damage from ingestion of products from Allium species (onions, garlic and related plants - see [39] for a list of plants) are particularly heavily implicated in the case of dogs and cats. Onion poisoning in dogs has been recognised since the 1930s [40] and is due mainly to sulphur-containing organic compounds, which give the characteristic odour of these foods [39]. These compounds are not destroyed by cooking or spoilage. Metabolites particularly propylsulphides are implicated in onion-induced oxidant damage of red cells in dogs and cats [41]. Animals probably need to consume about $0.5 \%$ of their body weight in onions to be affected [42], though of course the wet weight and the concentration of the active ingredient will be very variable between feedstuffs. Cats are less frequently affected by Allium spp. toxicity because of their dietary preferences though cases do occur, for example in ill animals fed on human baby food [43]. Ironically, the same sulphurcontaining organic compounds which cause harm to dogs and cats are associated with the therapeutic benefits of Allium spp. in humans [44]. Cats also have low hepatic glucuronidation capacity. They lack many uridine diphosphate glucuronyltransferases (UGTs) which makes them particularly susceptible to a number of iatrogenic drugs. They thus have a very poor ability to metabolise compounds such as acetaminophen and salicylic acid [45], for which there is no safe dose. In both dog and cat, overdoses with acetaminophen leads to the accumulation of metabolites such as p-aminophenol (PAP) in their red cells, which lack N-acetyltransferase 2 (NAT2) to remove it. The result is methaemoglobinaemia [46]. Overdose in other species including humans, by comparison, is associated with hepatic toxicity induced by the metabolite $\mathrm{N}$-acetyl-p-benzoquinoneimine (NADPQI) rather than oxidative damage to red cells. Heavy metals are also implicated in oxidative damage to red cells, particularly in dogs. Commoner causes include zinc toxicity (through ingestion of toys, bolts or coins containing high levels of zinc) [47] or iron overload. The latter is usually iatrogenic through iron injections or repeat transfusions. Some other common iatrogenic oxidants and toxins are listed in [Table 2], with a more complete list is provided in Haematology texts eg [7].

Table 2. Some toxins and iatrogenic oxidants causing haemolytic anaemia in dogs and cats.

\begin{tabular}{|l|}
\hline Acetaminophen (paracetamol) \\
\hline Acetylsalicylic acid (aspirin) \\
\hline Allium spp. \\
\hline Benzocaine \\
\hline Carprofen and other non-steroidal anti-inflammatories \\
\hline Copper \\
\hline Iron overload \\
\hline DL-methionine \\
\hline Methylene blue \\
\hline Phenylhydrazine \\
\hline Propylene glycol \\
\hline Vitamin K and vitamin K antagonists \\
\hline Zinc \\
\hline
\end{tabular}

\section{Red Cell Antioxidant Defence}

Notwithstanding the potential oxidative peril and their limited capacity for repair by protein synthesis, red cells must survive for some one hundred and twenty days in the case of humans and dogs, and about seventy days in the case of cats. Although the red cell is well equipped with antioxidant defences, problems arise when oxidative challenge exceeds the red cell antioxidant capacity. The result is oxidative damage to membrane lipids and proteins, and to haemoglobin itself. Oxidised haemoglobin, methaemoglobin (heme $\mathrm{Fe}^{3+}$ instead of the normal $\mathrm{Fe}^{2+}$ ), is unable to carry oxygen and is also liable to denaturation and precipitation as insoluble sulphHb containing Heinz bodies, or to form eccentrocytes in which the $\mathrm{Hb}$ is restricted to one side of the cell [13]. Other changes include crosslinking of the cytoskeleton, thiol oxidation, depletion of reduced glutathione and cation imbalance. The result is a fragile red cells with impaired rheology liable to intravascular haemolysis with anaemia, haemoglobinuria and poor oxygen-carrying capacity [48].

Antioxidant provision of red cells is provided by both enzymatic and non-enzymatic pathways. Five enzymes are heavily involved: catalase which reduces hydrogen peroxide to oxygen and water, glutathione reductase uses NADH to reduce oxidised methaemoglobin, superoxide dismutase scavenges superoxide anions generating hydrogen peroxide and oxygen in the process, and glutathione peroxidase uses NADPH to remove both red cell hydrogen peroxide and organic peroxides [49], as does membrane-associated perioxiredoxin- 2 which can be reduced via reduced glutathione, vitamin $\mathrm{C}$ or thioredoxin. Activities of these enzymes do vary between species [50-52]. Catalase activity in the red cells of difference species is very variable $[50,53,54]$. Expression 
in dog red cells occurs at about a tenth of the amount in humans whilst its specific activity is around a third that of human catalase [55]. As a result, overall catalase activity in dog red cells is a thirtieth that in humans $[53,55]$. Non-enzymatic defence includes reduced glutathione, vitamin $\mathrm{C}$ and vitamin $\mathrm{E}$. Therapeutic antioxidants include dosing with $\mathrm{N}$-acetyl cysteine, vitamin $\mathrm{C}$ and $\mathrm{E}$. None are particularly effective for rapid protection [39]. There is a need for more efficacious compounds. These must be effective in the short term and protect red cells from further oxidative damage and haemolysis without the requirement for prolonged metabolism. Some human compounds are listed in [Table 3].

Table 3. Antioxidants used in chemoprophylaxis of sickle cell disease in humans.

\begin{tabular}{|c|c|c|}
\hline Therapy & Effect & References \\
\hline Acetyl-L-carnitine & $\begin{array}{l}\text { Protects red cells from peroxidative } \\
\text { damage and maintains normal shape at } \\
\text { lower oxygen tensions }\end{array}$ & [68] \\
\hline$N$-Acetylcysteine & $\begin{array}{l}\text { Increases levels of reduced glutathione } \\
\text { and decreases haemolysis }\end{array}$ & {$[69,70]$} \\
\hline $\begin{array}{l}\text { Flavonoids } \\
\text { (quercetin, rutin \& } \\
\text { morin }\end{array}$ & $\begin{array}{l}\text { Show inhibitory effect on haemolysis } \\
\text { due to thiol group oxidation }\end{array}$ & [71] \\
\hline Glutamine & $\begin{array}{l}\text { Increases NAD redox potential and } \\
\text { NADH levels }\end{array}$ & {$[72,73]$} \\
\hline Hydroxyurea & $\begin{array}{l}\text { Reduces markers of oxidative stress, } \\
\text { decreases lipid peroxidation and } \\
\text { increases level of antioxidant enzymes }\end{array}$ & {$[74,75]$} \\
\hline $\begin{array}{l}\text { Iron chelators: } \\
\text { deferiprone \& } \\
\text { deferasirox }\end{array}$ & $\begin{array}{l}\text { Remove iron from the membrane of red } \\
\text { cells, decrease lipid peroxidation and } \\
\text { increase antioxidant capacity }\end{array}$ & {$[76,77]$} \\
\hline$\alpha$-lipoic acid & $\begin{array}{l}\text { Protects red cells from peroxyl radical } \\
\text { induced haemolysis, increases levels } \\
\text { of reduced glutathione and increased } \\
\text { antioxidant gene expression }\end{array}$ & {$[78,79]$} \\
\hline Melatonin & $\begin{array}{l}\text { Increases levels of antioxidants and } \\
\text { reduces rate of haemolysis }\end{array}$ & {$[80]$} \\
\hline Statins & $\begin{array}{l}\text { Protects against oxidative damage by } \\
\text { increasing nitric oxide metabolites and } \\
\text { C-reactive protein }\end{array}$ & {$[81,82]$} \\
\hline Vitamin $\mathrm{C}$ and $\mathrm{E}$ & $\begin{array}{l}\text { Decreases production of reactive oxygen } \\
\text { species, increases levels of reduced } \\
\text { glutathione and reduces haemolysis }\end{array}$ & [83] \\
\hline
\end{tabular}

\section{References}

1. Nikinmaa M (1990) Vertebrate red blood cells. Zoophysiology ed. S.D. Bradshaw. Berlin Heidelberg: Springer-Verlag.

2. Arese P and E Schwarzer (2003) Metabolic disorders in Red cell membrane transport in health and disease, I. Bernhardt and JC Ellory, Editors. Springer: Berlin. Pg No: 525-548.

3. Kaneko JJ, JW Harvey, ML Bruss (2008) Clinical Biochemistry of Domestic Animals. Academic Press: New York.

4. Tosteson DC and JF Hoffman (1960) Regulation of cell volume by active cation transport in high and low potassium sheep red cells. Journal of general physiology 44: 169-194.

5. Parker JC (1997) Solute and water movement in dog and cat red blood cells., in Membrane Transport in Red cells, JC Ellory and VL Lew, Editors. Academic Press: London. Pg No: 427-465.
6. Fujise $\mathrm{H}$ (1997) $\mathrm{K}^{+}$-Cl- cotransport and volume regulation in the light and the dense fraction of high $\mathrm{K}^{+}$dog red blood cells. American Journal of Physiology 273: R2991-R2998.

7. Weiss D and J Wardrop (2010) Schalm's Veterinary Hematology. Wiley-Blackwell: Iowa, USA.

8. Sidell BD and KM O'Brien (2006) When bad things happen to good fish: the loss of hemoglobin and myoglobin expression in Antarctic ice fishes. Journal of Experimental Biology 209: 1791-1802.

9. Taketa F, MR Smits, JL Lessard (1968) Hemoglobin heterogeneiry in the cat. Biochemical and Biophysical Research Communications 30: 219-226.

10. Harvey JW and JJ Kaneko (1977) Mammalian erythrocyte metabolism and oxidant drugs. Toxicological and Applied Pharmacology 42: 253-261.

11. Reischl E (2007) Distribution, adaptation and physiological meaning of thiols from vertebrate hemoglobins. Comparative Biochemistry and Physiology Part C 146: 22-53.

12. Vitturi DA (2013) Antioxidant functions for the hemoglobin beta-93 cysteine residue in erythrocytes and in the vascular compartment in vivo. Free Radical Biology and Medicine 55: 1-23.

13. Hamilton MN and SJ Edelstein (1973) Cat hemoglobin: pH dependence of cooperativity and ligand binding. Journal of Biological Chemistry 249: 1323-1329.

14. Christopher MM, JG White, JW Eaton (1990) Erythrocyte pathology and mechanisms of Heinz body-mediated hemolysis in cats. Veterinary Pathology 27: 299-310.

15. Blue JT, L Weiss (1981) Vascular pathways in nonsinusoidla red pulp: an electron microscope study of the cat spleen. American Journal of Anatomy 161: 135-168.

16. Lessard JL and F Taketa (1969) Multiple hemoglobins in fetal, newborn and adult cats. Biochemical et Biophysical Acta 175: 441-444.

17. Giger U (1991) Geographical variation of the feline blood type frequencies in the United States. Feline Practice 19: 21-27.

18. Bunn HF (1971) Differences in the interaction of 2,3-diphosphoglycerate with certain mammalian hemoglobins. Science 172: 1049-1050.

19. Mauk AG and F Taketa (1972) Effects of organic phosphates on oxygen equilibria and kinetics of -SH reaction in feline hemoglobins. Archives of Biochemistry and Biophysics 150: 376-381.

20. Rapoport S and GM Guest (1941) Distribution of acid-soluble phosphorus in the blood cells of various vertebrates. Journal of Biological Chemistry 138: 269-282.

21. Zaldivar-Lopez S (2017) Comparative genomics of canine hemoglobin genes reveals primary of beta subunit delta in adult carnivores. BMC Genomics 18: 141.

22. Low PS, P Rathinavelu, ML Harrison (1993) Regulation of glycolysis via reversible enzyme binding to the membrane protein, band 3. Journal of Biological Chemistry 268: 14627-14631.

23. Chu H (2016) Reversible binding of hemoglobin to band 3 constitutes the molecular switch that mediates $\mathrm{O} 2$ regulation of erythrocyte properties. Blood 128: 2708 2716.

24. Kim HD and MG Luthra (1976) Pig reticulocytes: I. Transitory glucose permeability and metabolism. American Journal of Physiology 230: 1668-1675.

25. Young JD, ARP Paterson, PJF Henderson (1985) Nucleoside transport and metabolism in erythrocytes from the Yucatan miniature pig. Evidence that inosine functions as an in vivo energy substrate. Biochimica et Biophysica Acta 842: 214 224.

26. Pritlove DC (2006) Novel placental expression of 2,3-biphosphoglycerate mutase. Placenta 27: 924-927.

27. Van Wijk R and WW van Solinge (2005) The energy-less red blood cell is lost: erythrocyte enzyme abnormalities of glycolysis. Blood 106: 4034-4042.

28. Mohanty JG, E Nagababu, JM Rifkind (2014) Red blood cell oxidative stress impairs oxygen delivery and induces red blood cell aging. Frontiers in Physiology 5: $1-6$.

29. Fibach E (2014) Involvement of oxidative stress in hemolytic anemia, in Systems Biology of Free Radicals and Antioxidants, I. Laher, Editor. Springer-Verlag: Berlin Heidelberg 2499-2516.

30. Sies H (1997) Oxidative stress: oxidants and antioxidants. Experimental Physiology 82: 291-295.

31. Hebbel RP (1982) Spontaneous oxygen radical generation by sickle erythrocytes. Journal of Clinical Investigation 70: 1253-1259.

32. Sadrzadeh SMH (1984) Hemoglobin: a biologic Fenton reagent. Journal of Biological Chemistry 259: 14354-14356.

33. George A (2013) Erythrocyte NADPH oxidase activity modulated by Rac GTPases, PKC, and plasma cytokines contributes to oxidative stress in sickle cell disease. Blood 121: 2099-2107.

34. Jaffe ER (1974) The formation and reduction of methemoglobin in human erythrocytes, in Cellular and molecular biology of erythrcoytes, H. Yoshikawa and S.M. Rapaport, Editors. University Park Press: Baltimore. 345-376. 
35. Edwards CJ and J Fuller (1996) Oxidative stress in erythrocytes. Comparative Haematology International 6: 24-31.

36. Zweier JL and MA Talukder (2006) The role of oxidants and free radicals in reperfusion injury. Cardiovascular Research 70: 181-190.

37. Balagopalakrishna C (1996) Production of superoxide from hemoglobin-bound to oxygen under hypoxic conditions. Biochemistry 35: 6393-6398.

38. Yamoto O and Y Maede (1992) Susceptibility to onion-induced hemolysis in dogs with hereditary high erythrocyte reduced glutathione and potassium concentrations American Journal of Veterinary Research 53: 134-137.

39. Salgado BS, LN Monteiro, NS Rocha (2011) Allium species poisoning in dogs and cats. Journal of Venomous Animals and Toxins including Tropical Diseases 17: 4-11.

40. Harvey JW and D Rackear (1985) Experimental onion-induced hemolytic anemia in dogs. Veterinary Pathology 22: 387-392.

41. Zhao J (2017) Therapeutic effect of hydrogen injected subcutaneously on onion poisoned dogs. Journal of Veterinary Research 61: 527-533.

42. Cope RB (2005) Allium species poisoning in dogs and cats. Veterinary Medicine Pg No: $562-566$.

43. Robertson JE, MM Christopher, QR Rogers (1998) Heinz body formation in cats fed baby food containing onion powder. Journal of the American Veterinary Medical Association 212: 1260-1266.

44. Augusti KT (1996) Therapeutic values of onion and garlic. Indian Journal of Experimental Biology 34: 634-640.

45. Court MH (2013) Feline drug metabolism and disposition: pharmacokinetic evidence for species differences and molecular mechanisms. Veterinary Clinics of North America Small Animal Practice 43: 1039-1054.

46. McConkey SEM, DM Grant, AE Cribb (2009) The role of Para-aminophenol in acetaminophen-induced methaemogloinaemia in dogs and cats. Journal of Veterinary Pharmacology and Therapeutics 32: 585-595.

47. Bexfield N, J Archer, M Herrtage (2007) Heinz body haemolytic anaemia in a dog secondary to ingestion of a zinc toy: a case report. Veterinary Journal 174: 414-417.

48. Hasegawa S (1993) Impaired deformability of Heinz-body-forming red cells. Bio rheology 30: 275-286.

49. Nagababu E, FJ Chrest, JM Rifkind (2003) Hydrogen-peroxide-induced heme degradation in red blood cells: the protective roles of catalase and glutathione peroxidase. Biochimica et Biophysica Acta 1620: 211-217.

50. Maral J, K Puget, AM Michelson (1977) Comparative study of superoxide dismutase, catalase and glutathione peroxidase levels in erythrocytes of different animals. Biochemical and Biophysical Research Communications 77: 1525-1535.

51. Stolk JN and RP Smith (1966) Species differences in methaemoglobin reductase activity. Biochemical Pharmacology 15: 343-351.

52. Owen JL and JW Harvey (2012) Hemolytic anemia in dogs and cats due to erythrocyte enzyme deficiences. Veterinary Clinics of North America Small Animal Practice 42: 73-84.

53. Richardson M (1952) Study of catalase in erythrocytes and bacteria. II. Catalase activity in erythrocytes from different species of normal animals and from normal humans. Archives of Biochemistry and Biophysics 42: 124-134.

54. Allison AC, W Rees, GP Burn (1957) Genetically-controlled differences in catalase activity of dog erythrocytes. Nature 180: 649-650.

55. Nakamura K (1998) A low catalase activity in dog erythrocytes is due to a very low content of catalase protein despite having a normal specific activity. International Journal of Biochemistry and Cell Biology 30: 823-831.

56. Smith JE (1983) Hereditary elliptocytosis with protein band 4.1 deficient in the dog. Blood 61: 373-377.

57. Fletch SM and PH Pinkerton (1973) Animal model for human disease: inherited hemolytic anemia in stomatocytosis in the Alaskan Malamute dog. Journal of Pathology 71: 477-480.

58. Slappendel RJ, W Renooji, JJ de Bruijne (1994) Normal cations and abnormal membrane lipids in the red blood cells of dogs with familial stomatocytosishypertrophic gastritis. Blood 84: 904-909.
59. Bonfanti U (2004) Stomatocytosis in 7 related standard Schnauzers. Veterinary Clinical Pathology 33: 234-249.

60. Harvey JW (1991) Methaemoglobin reductase deficiency in dogs. Comparative Haematology International 1: 55-59.

61. Harvey JW, M Dahl, ME High (1994) Methemoglobin reductase deficiency in a cat. Journal of the American Veterinary Medical Association 205: 1290-1291.

62. Harvey JW (2006) Inherited methaemoglobin redutase deficiency in dogs and cats. Veterinary Clinical Pathology 35: 144-156.

63. Kohn B, MH Goldschmidt, AE Hohenhaus (2000) Anemia, splenomegaly, and increased fragility of erythrocytes in Abyssinian and Somali cats. Journal of the American Veterinary Medical Association 217: 1483-1491.

64. Tritschler C (2016) Increased erythrocytic osmotic fragility in anemic domestic shorthair and purebred cats. Journal of Feline Medicine and Surgery 18: 462-470.

65. Giger U (1985) Inherited phosphofructokinase deficiency in dogs with hyperventilation-induced haemolysis: increased in vitro and in vivo alkaline fragility of erythrocytes. Blood 65: 345-351.

66. Harvey JW and JE Smith (1994) Haematology and clinical chemistry of English springer spaniel dogs with phosphofructokinase deficiency. Comparative Haematology International 4: 70-75.

67. Juvet F (2013) Erythrocyte pyruvate kinase deficiency in three West Highland white terriers in Ireland and the UK. Irish Veterinary Journal 66: 12.

68. Ronca F (1994) Effect of L-proprionyl carnitine on in-vitro membrane alteration of sickle-cell anaemia erythrocytes. International Journal of Tissue Reaction 16: 187-194.

69. Pace BS (2003) Effects of N-acetyl cysteine on dense cell formation in sickle cell disease. American Journal of Hematology 73: 26-32.

70. Nur E (2012) N-acetyl cysteine reduces oxidative stress in sickle cell patients. Annals of Hematology 91: 1097-1105.

71. Asgary S, G Naderi, N Askari (2005) Protective effects of flavonoids against red blood cell hemolysis by free radicals. Experimental Clinical Cardiology 10: 88-90.

72. Niihara Y (2005) L-glutamine therapy reduces endothelial adhesion of sickle red blood cells to human umbilical vein endothelial cells. BMC Blood Disorders 5: 1-7.

73. Niihara Y (2018) A phase 3 trial of L-glutamine in sickle cell disease. New England Journal of Medicine 379: 226-235.

74. Ghatpande SS (2008) Pharmaco-proteomic study of hydroxyurea-induced modifications in the sickle red blood cell membrane proteome. Experimental Biology and Medicine 233: 1510-1517.

75. Torres LdS (2012) The influence of hydroxyurea on oxidative stress in sickle cell anemia. Reviews of Brazilian Hematology and Hemoter 34: 421-425.

76. Shalev O (1995) Deferiprone (L1) chelates pathologic iron deposits from membrane of intact thalassemic and sickle red blood cells both in vitro and in vivo. Blood 86: 2008-2013.

77. Belini Jr E (2012) Oxidative stress and antioxidant capacity in sickle cell anaemia patients receiving different treatments and medications for different periods of time. Annals of Hematology 91: 479-489.

78. Maragnon K (1999) Comparison of the effect of alpha-lipoic acid and alphatocopherol supplementation on measures of oxidative stress. Free Radical Biology and Medicine 27: 1114-1121.

79. Vichinsky E (2012) Emerging 'A' therapies in hemoglobinopathies: agonists, antagonists, antioxidants, and arginine. ASH Education Programme 1: 271-275.

80. da Silva DG (2015) Potential utility of melatonin as an antioxidant therapy in the management of sickle cell anemia. Journal of Pineal Research 58: 178-188.

81. Hoppe C (2011) A pilot study of the short term use of simvastatin in sickle cell disease: effects on markers of vascular dysfunction. British Journal of Haematology 153: 655-663.

82. Davnignon J (2004) Beneficial pleiotropic effects of statins. Circulation 15: 11139 11143 .

83. Amer J (2006) Red blood cells, platelets and polymorphonuclear neutrophils of patients with sickle cell disease exhibit oxidative stress that can be ameliorated by antioxidants. British Journal of Haematology 132: 108-113.

\section{Citation:}

Gibson JS, Wadud R, Lu D C-Y, Brewin JN, Rees DC (2019) Oxidative stress and haemolytic anaemia in dogs and cats: a comparative approach. Integr J Vet Biosci Volume 3(3): 1-5. 